\title{
Price transmission in regional beef markets: Australia, China and Southeast Asia
}

\author{
Xiaoxia Dong ${ }^{1 *}$, Scott Waldron ${ }^{2}$, Colin Brown², Jing Zhang ${ }^{2}$ \\ ${ }^{1}$ Agricultural Information Institute, Chinese Academy of Agricultural Sciences, Beijing 100081, China, ${ }^{2}$ School of Agriculture and Food \\ Sciences, University of Queensland, Brisbane 4072, Australia
}

\section{A B S T R A C T}

With increasing trade volumes in the Asian region, it could be expected that beef markets are becoming increasingly integrated. Major beef exporters or importers can be expected to lead others, but others can be separated by obstacles to trade or small trade volumes. This paper examines price transmission between the key regional beef markets of Australia, China, Indonesia and Vietnam. It draws on quarterly price data from 2005 to 2015 and methods including co-integration analysis, granger causality test, and vector error correction model and impulse response function. The results show that log-run equilibrium relationships exist in two of the trading relationships, where the beef price in Indonesia is affected by the Australian market while the beef price in Vietnam is impacted by the Chinese market. However, Australia and China's beef prices are not impacted by Indonesian or Vietnamese prices. Reasons behind these price interrelationships are discussed.

Keywords: Australia; Beef market; China; Price transmission; Southeast Asia

\section{INTRODUCTION}

The beef sector in the China and Southeast Asia has undergone major change over the last 15 years. Led by China and Vietnam, incomes and urbanization increased per capita beef consumption in the region by $1.9 \%$ per year between 2000 and 2014, far higher than the increases in per capita beef production of $0.8 \%$. The shortfall between consumption and production has resulted in very high growth in the trade of cattle and beef of $16 \%$ and also seen an average rise in beef prices of $6.5 \%$ per annum over the period (Waldron et al., 2017). These developments have proved fortuitous for Australia in absorbing high cattle turnoff numbers from an extended drought in the 2010s.

A brief overview of aggregate statistics (FAOStat, accessed January 2017) shows that Australia, China and Southeast Asian countries have become significant countries in the global beef and cattle trade. Australia was the third largest beef exporter in the world in 2015 accounting for 15\% of world export volumes. Beef exports reached 1.4 million tons in 2015, an increase of 36\% over 2005 levels. More than 1.3 million head were exported which at $200 \mathrm{kgs}$ carcass weight equivalent (cwe) adds another 234kt cwe, and an annual average increase of $8.8 \%$ from 2005 to 2015 . China is the third largest beef producer in the world. However, low growth in beef production for a decade alongside a large increase in demand meant that formal beef imports reached 474kt in 2015, a massive 415 times more than in 2005. At least an additional one million tons was imported informally making China the biggest net importer of beef in the world. Beef imports into Southeast Asia have increased up 400kt in 2014, an increase of 57\% over 2005.

Australian beef exports to China and Southeast Asia have increased dramatically over the last decade. Australia exported 155kt beef to China in 2015, accounting for $12 \%$ of Australian beef exports, up from just $0.2 \%$ in 2005 . Australia exported 107kt of beef to Southeast Asia along with more than one million a further 1,030,483 head of live cattle, which at $200 \mathrm{kgs}$ carcass weight equivalent (cwe) adds another 206kt cwe in 2015, accounting for $18 \%$ of total beef and live cattle exports of Australia or double that in 2005. Within Southeast Asian countries, Australia exported most beef to Indonesia (41kt) along with a further 618,800 head of live cattle. Vietnam is Australia's second

\footnotetext{
*Corresponding author:

Scott Waldron, School of Agriculture and Food Sciences, University of Queensland, Brisbane 4072, Australia. Tel.: +61 733652103.

E-mail: scott.waldron@uq.edu.au.

Received: 02 March 2017; $\quad$ Accepted: 06 February 2018
} 
biggest export market in Southeast Asia with 5kt of beef and 313,000 head of live cattle in 2015. Both Indonesia and Vietnam accounted for nearly three-fourth of total exports volume from Australia to Southeast Asia.

With rapid increasing in trade, it could be expected that regional beef markets are becoming increasingly integrated. Price trends and their determinants are of major interest to government, industry and development sectors throughout the region. In Australia, prices have been crucial to industry viability in a country that exports $61 \%$ of its cattle and beef. High prices can also have important development impacts for about 20 million small-holders in developing countries in the region that raise cattle, from Myanmar to Laos and Cambodia. Stakeholders in (net) importing countries - especially China, Indonesia and Vietnam - are also concerned about producer prices. High beef prices in these countries in recent years have led to increasingly liberal trade policies in an attempt to moderate the price rises and have included lowering tariffs, diversifying import sources, relaxing disease protocols and turning a blind eye to large informal imports of cattle and beef. Thus analyzing market integration and price transmission is a crucial in better understanding these price trends and their determinants.

The objective of this study is to identify price transmission relationships in regional beef markets based on beef retail prices in the four countries of Australia, China, Indonesia and Vietnam. The paper is organized as follows. Section 2 briefly presents relevant literature. Section 3 describes the time series methods and data used in the empirical analysis. Section 4 reports empirical results of the analysis, factors influencing of the regional price transmission discusses in section 5. The final section presents conclusions.

\section{Literature review}

As a major livestock product, the literature on beef price transmission has grown rapidly over the last decade. Most studies focus on price transmission in domestic markets (Fousekis et al., 2016; Pozo et al., 2013; Bakucs and Fertő, 2006; Lloyd et al., 2006; Sanjuan and Dawson, 2003; Goodwin and Holt, 1999; Chang and Griffith, 1998; Griffith and Piggott, 1994). Chang and Griffith (1998) analyzed the transmission relationship between producer price, wholesale price and retail prices of Australian beef based on the monthly data from 1971 to 1994 , and found long-term co-integration relationship existing among the three price series. Bakucs and Fertő (2006) tested the price relationship of Hungarian beef markets from producer to retailer, and found that the transmission between the upstream and downstream in the industrial chain was symmetrical in both the long and short terms. Based on monthly data from 2001 to 2012, Pozo et al. (2013) examined the relationship between the upstream and downstream prices of the US beef market. They found that the transmission relationship between the producer price, the wholesale price and the retail price is symmetric in the United States (US) beef market. Fousekis et al. (2016) employed the Nonlinear ARDL model and monthly data for the period 1990 to 2014 and found asymmetry in magnitude for the pair of markets farm-wholesale in the U.S. beef market.

With increasing trade liberalization, several studies have examined the impact of international markets on domestic markets and the relationship between beef prices in major countries. Dries and Unnevehr (1990) identified the influence of policy interventions in major trading nations on price integration in the world beef market. They found that the US is the price leader in world beef markets due to market size and policies. However, European Community (EC) policies that closed EC imports isolated EC prices from other markets. Diakosavvas (1995) found that Australian and US beef producer (monthly) prices were integrated during the period of 1972-1993, but that the intensity of integration did not increase over time. In accordance, Australian beef prices cannot be regarded as a "reference price" of world beef. Brester and Wohlgenant (1997) examined the impact of GATT/Uruguay Round Trade Negotiations on US beef and cattle prices. They found that GATT/Uruguay Round will cause asymmetric effects on ground and table cut beef retail price, and increases in fed and feeder cattle prices. Based on data from 1993 to 2010, Ghoshray (2011) found that longterm international market prices impact on Thai beef prices, but the short term effects were insignificant. Yoon and Brown (2016) found the Trans Pacific Partnership (TPP) countries are well integrated in their beef trade, and asymmetric pricing behavior in beef trade exits due to quality difference, imperfect competition, and trade policy.

The literature on price transmission has debated extensively the constraints facing exporting countries in the beef markets, with most of the attention paid to developed countries such as America, Australia or Western Europe. Only a few studies focus on markets in developing and transition countries. To our knowledge, there are no papers in the literature on price transmission in the region of Australia, China and Southeast Asia. This paper draws on detailed beef price data from Australia, China, Indonesia and Vietnam to examine price transmission in these key regional markets. In contrast to the other studies mentioned above, our study examines market integration and price transmission relationship between major trading partners, consisting of major exporters (Australia, a developed country), major importers (China and Indonesia (developing countries) and Vietnam (an importer, exporter 
and transit country). This study could be used to evaluate the price impacts each other between trading partners and to assess the impact of formal trade and informal trade on domestic prices and price transmission. Our results can also contribute to the discussion on impacts of beef production and trade policies in Australia, China and Southeast Asian countries.

\section{MATERIALS AND METHODS}

\section{Methods}

Initially price transmission in horizontal market were examined using correlation coefficients (Lele, 1967; Thakur, 1974; Timmer, 1999). Over time, the research methods have become more sophisticated to include the Co-integration test, Granger causality test, Vector autoregressive (VAR) model, Vector error correction (VEC) model, Error correction model (ECM), Impulse Response Function (IRF), General to Specific (GETS) model, and Finite Distributed Lag (FDL) model (Gonzale and Helfand, 2001; Theodoros et al., 2009; Dong et al., 2014). One of the primary methods used over the last two decades on empirical research into agricultural price transmission has been VEC model which is outlined below (Fackler and Goodwin 2001; Miljkovic, 1999; Listorti, 2009; Listorti and Esposti, 2012).

Based on the literature, this study uses a series of time series methods to test the price transmission of beef market in Australia, China, Vietnam and Indonesia. First, the Augmented Dicky-Fuller (ADF) method is used to test the stationarity of the beef price series in four countries. Second, the Johansen co-integration test is used to test the long-run equilibrium between the four countries' beef price series. Third, the Granger causality test is used to analyze the impact direction of the price transmission relationship. Fourth, the VEC model is used to verify the short-run equilibrium relationship and the degree of specific impact between the four countries' beef price series. Finally, impulse response function analysis furtherly informs the specific dynamic relationships between influential time series. As central to the analysis, the description of methods below will focus on the VEC model.

The VEC model is a special case of the VAR for variables that are stationary in their differences. It describes a system in which each variable is a function of its own lag of the difference and the lags of the differences of the other variable in the system (Granger, 2004). If there are cointegrated relationship between the dependent variable and the independent variable(s), an ECM representation generates co-integrated series (Engle and Granger, 1987). According to Harris (1995), Granger's theorem for dynamic modeling provides the error correction model with immunity from the spurious regression problem in practical, provided that the terms in levels co-integrate. The VEC model for beef price in the four countries can be written as follows,

$$
\begin{aligned}
\Delta P_{t}^{a u}= & \alpha_{0}+\mu E C M_{t-1}+\sum_{i=1}^{n} \beta_{i} \Delta P_{t-i}^{a u}+\sum_{i=1}^{n} \gamma_{i} \Delta P_{t-i}^{c n} \\
& +\sum_{i=1}^{n} \delta_{i} \Delta P_{t-i}^{v n}+\sum_{i=1}^{n} \theta_{i} \Delta P_{t-i}^{i d}+\varepsilon_{t} \\
\Delta P_{t}^{c n}= & \alpha_{0}+\mu E C M_{t-1}+\sum_{i=1}^{n} \beta_{i} \Delta P_{t-i}^{c n}+\sum_{i=1}^{n} \gamma_{i} \Delta P_{t-i}^{a u} \\
& +\sum_{i=1}^{n} \delta_{i} \Delta P_{t-i}^{v n}+\sum_{i=1}^{n} \theta_{i} \Delta P_{t-i}^{i d}+\varepsilon_{t}
\end{aligned}
$$

$$
\begin{aligned}
\Delta P_{t}^{v n}= & \alpha_{0}+\mu E_{C} M_{t-1}+\sum_{i=1}^{n} \beta_{i} \Delta P_{t-i}^{v n}+\sum_{i=1}^{n} \gamma_{i} \Delta P_{t-i}^{a n} \\
& +\sum_{i=1}^{n} \delta_{i} \Delta P_{t-i}^{c n}+\sum_{i=1}^{n} \theta_{i} \Delta P_{t-i}^{i d}+\varepsilon_{t}
\end{aligned}
$$

$$
\begin{aligned}
\Delta P_{t}^{i d}= & \alpha_{0}+\mu E_{C} M_{t-1}+\sum_{i=1}^{n} \beta_{i} \Delta P_{t-i}^{i d}+\sum_{i=1}^{n} \gamma_{i} \Delta P_{t-i}^{a u} \\
& +\sum_{i=1}^{n} \delta_{i} \Delta P_{t-i}^{c n}+\sum_{i=1}^{n} \theta_{i} \Delta P_{t-i}^{v n}+\varepsilon_{t}
\end{aligned}
$$

In Equation(1)-(4) $P_{t}^{a u} P_{t}^{c n} P_{t}^{v n} P_{t}^{i d}$ denotes beef prices of Australia, China, Vietnam and Indonesia respectively in present. $P_{t-i}^{a u} P_{t-i}^{c n} P_{t-i}^{v n} P_{t-i}^{i d}$ denotes beef prices of Australia, China, Vietnam and Indonesia in the time of $\mathrm{t}-\mathrm{i}$ respectively. The coefficient vectors $\beta_{i}, \gamma_{i}, \delta_{i}, \theta_{i}$, presents the impact of short term fluctuations of the explanatory variables in the lag period on the short term fluctuations of explained variables in the current period. $E C M_{t-1}$ is the error correction term whose coefficient vector $\mu$ reflects the intensity of adjustments when the variables in the short run relation deviating from the long-term equilibrium state. The number of ECM $M_{t-1}$ is determined by the number of Johansen tests $\operatorname{Rank}(\pi) . \alpha_{0}$ is a constant term, $\varepsilon_{t}$ is a residual term.

\section{Materials}

The analysis draws on time series data from 2005 to 2015. The sources of data in the four countries are:

- China: Beef prices are monitored in key markets throughout the country including Beijing, and are 
reported weekly in $\mathrm{RMB} / \mathrm{kg}$ including through the China Animal Husbandry Statistics released by Animal Husbandry Department of Ministry of Agriculture.

- Vietnam: Monthly beef prices in Hanoi are collected and reported by the Ministry of Agriculture and Rural Development in the local currency of $\mathrm{VND} / \mathrm{kg}$.

- Indonesia: Weekly beef prices in Jakarta are published in the "Bulletin of Analysis of developments in agricultural commodity prices" in IDR/kg by the Ministry of Agriculture.

- Australia: Retail price data is drawn from the Australian Bureau of Statistics on a quarterly basis (for inflation monitoring purposes), reported in AUD/kg, and available through Meat and Livestock Australia.

To avoid distortions from using national averages, price data is drawn from major (capital) cities of respective countries, although only averaged national data is available for Australia. Prices are reported for different periods (weeks, months, and quarters) in the four countries but quarterly data was used in the analysis as this was the minimum period of the beef price statistics available (Australia). The price data in all countries was converted to USD for the comparison analysis and are nominal prices. The prices used in the analysis were also transformed to a natural logarithm to eliminate the possible heteroscedasticity. To facilitate the discussion below, the time series are labelled as Australia (LNAU), China (LNCN), Vietnam (LNVN) and Indonesia (LNID).

\section{RESULTS AND DISCUSSION}

\section{Price transmission relationship analysis}

Fig. 1 and Table 1 provide a descriptive and visual overview of beef retail prices in Australia, China, Vietnam, and Indonesia from 2005 to 2015. The series reveals: (a) that beef prices in general have increased but there has been some fluctuations over the period, where China and Australia series show a large dispersion between years in Standard Deviation, followed by Indonesia and Vietnam (Table 1); (b) there appear to be some similarities in the patterns of these price series suggesting some degree of correlation. However, further formal empirical testing is required to establish relationships.

In order to avoid the spurious regressions in the econometric analysis, the stationarity of each price series first needs to be determined by the extended DickeyFuller test (ADF), before examining the co-integration relationship of beef price series in four countries. Table 2 shows the results of the unit root test, which shows that the four beef price series are not stationary during the period of 2005-2015, but are stationary after the first difference. Therefore all the prices series can be defined as I (1), thus the co-integration theory can be applied to analyze the long-term equilibrium relationship among the price series.

As a study of beef prices in four different countries, the Johansen co-integration test was used to identify whether there was a co-integration relationship between beef prices in Australia, China, Vietnam and Indonesia. Table 3 shows the results of the Johansen co-integration test, which was conducted with the lag order of 1 (determined by the Akaike information criterion), and with the option of an intercept term (no trend). It found that both the Trace test and Max-eigen unit root test reject the null hypothesis of $r=0$, but cannot reject $r \leq 1$ at a $5 \%$ level of significance. It indicates that there is at least one co-integrating relationship, and indeed a long-term stable equilibrium relationship between the prices of beef in four countries.

The existence of co-integration and long-term equilibrium relationship among the four price series also implies that

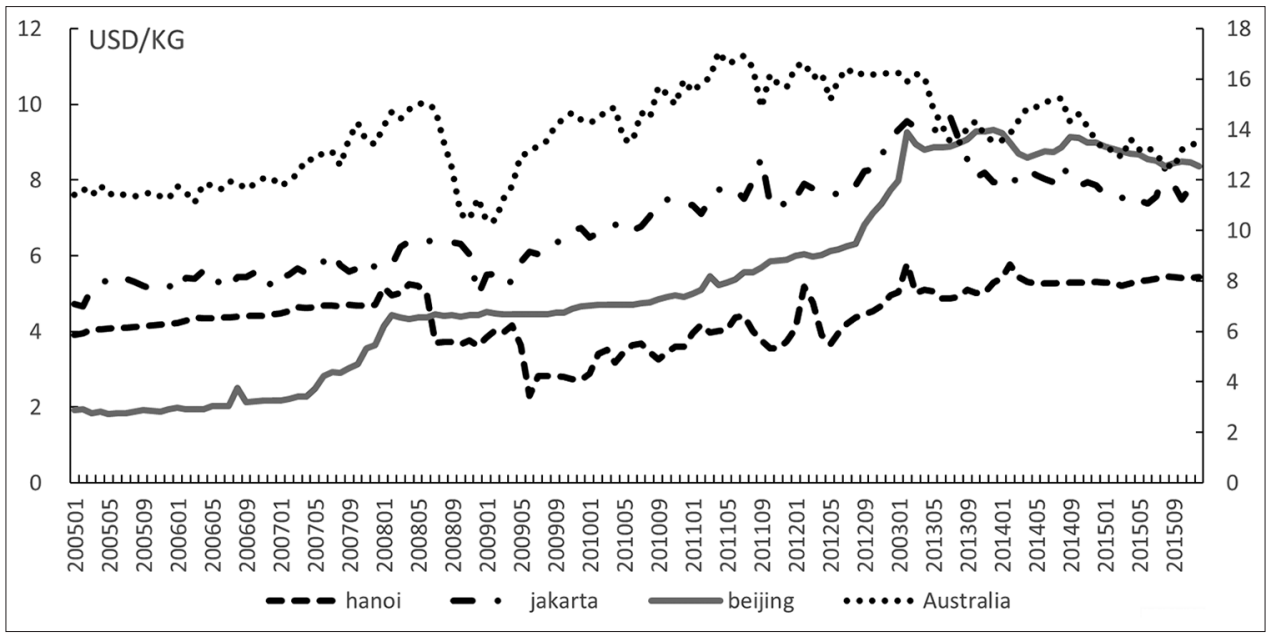

Fig 1. Beef retail price in Australia, Beijing, Jakarta and Hanoi from 2005 to 2015. Notes: left axes are Hanoi, Jakarta and Beijing. Right axes is Australia. 
there is at least one Granger causality between each other (Narayan and Smyth, 2004), which is often used to verify whether two-way causality relationship exists between the price of beef in the four countries. The results of the Granger causality test are shown in Table 4 which reveals several relationships namely: a) the Chinese beef price is a Granger cause of Vietnamese beef price; b) the Australian beef price is the Granger reason of the Indonesian beef price; c) there is no Granger causality existing between the Australian beef price and the Chinese beef price; and d) Australian and Chinese beef prices are independent from the other three countries.

Based on the analysis above, the VEC model was established to test the short-term integration of beef market in these four countries, as shown in Table 5. In the equations that use Australian and Chinese beef prices as explanatory variables (the columns of $\triangle \mathrm{LNAU}$ and $\triangle \mathrm{LNCN}$ ), the prices of the other three countries had no effect on their current prices, except for the influence of themselves in the previous period. In the equation that uses Vietnamese beef prices as explanatory variables, the price of Chinese beef has a significant impact on the price of Vietnamese beef. The coefficient is 0.3226 indicates that a change in the price of Chinese beef in the previous period of $10 \%$ leads Vietnamese beef prices to change in the same direction by $3.226 \%$. Changes in Australian

Table 1: Descriptive statistics of the beef price data in four countries

\begin{tabular}{lcccc} 
Variable & Mean & Standard Devision & Min & Max \\
\hline Australia & 13.7932 & 1.7457 & 10.33 & 17.08 \\
Beijing & 5.3459 & 2.5240 & 1.81 & 9.32 \\
Hanoi & 4.3879 & 0.7591 & 2.30 & 5.79 \\
Jakarta & 6.8692 & 1.2702 & 4.67 & 9.69 \\
\hline
\end{tabular}

Table 2: Test for unit root and stationary

\begin{tabular}{lccllc}
\hline Variable & ADF value & 5\% critical value & Test Type & Result & MacKinnon value \\
\hline LNAU & -1.818 & -3.524 & $(c, t, k)$ & nonstationary & 0.6958 \\
LNCN & -0.358 & -3.524 & $(c, t, k)$ & nonstationary & 0.9881 \\
LNVN & -2.041 & -3.524 & $(c, t, k)$ & nonstationary & 0.5787 \\
LNID & -2.028 & -3.524 & $(c, t, k)$ & nonstationary & 0.5862 \\
$\triangle$ LNAU & -5.160 & -3.524 & $(c, t, k)$ & stationary & 0.0001 \\
$\triangle$ LNCN & -4.204 & -3.524 & $(c, t, k)$ & stationary & 0.0044 \\
L LNVN & -5.107 & -3.524 & $(c, t, k)$ & stationary & 0.0000 \\
$\triangle$ LNID & -7.821 & -3.524 & $(c, t, k)$ & stationary & 0.0001 \\
\hline
\end{tabular}

Note: a) All of the symbol $\triangle$ in this paper means the first difference; b) in the column of testing type, $c$ denotes constant; $t$ denotes trend; $k$ was lagging number.

Table 3: Johansen co-integration test results

\begin{tabular}{lccccc}
\hline Null Hypothesis & Parms & LL & Max Eigen & Trace Statistic & 5\% Critical Value \\
\hline$r=0$ & 4 & 245.0699 & - & 51.1981 & 47.21 \\
$r \leq 1$ & 11 & 259.8000 & 0.4881 & $21.7380^{*}$ & 29.68 \\
$r \leq 2$ & 16 & 266.7576 & 0.2711 & 7.8227 & 15.41 \\
$r \leq 3$ & 19 & 269.4252 & 0.1142 & 2.4876 & 3.76 \\
$r \leq 4$ & 20 & 270.6690 & 0.0550 & -- & -- \\
\hline
\end{tabular}




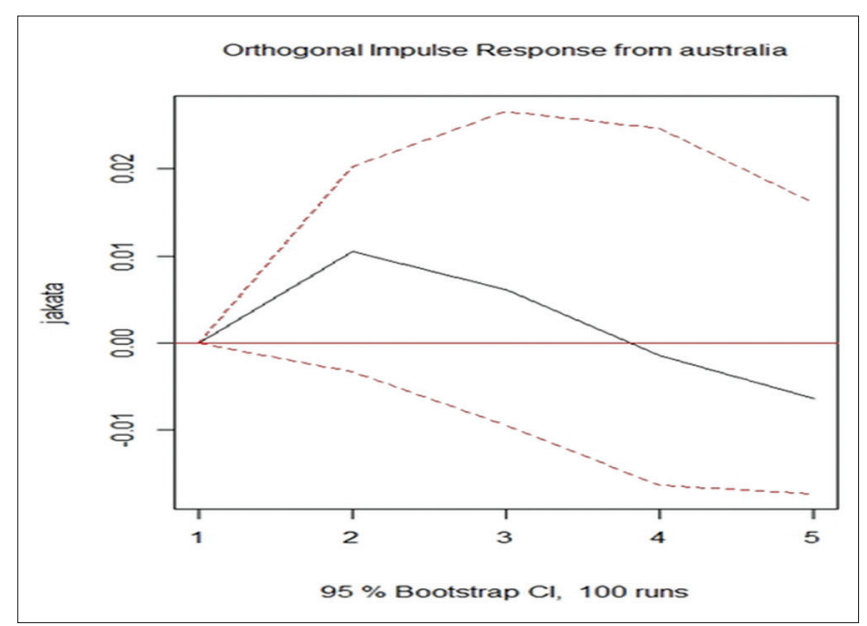

Fig 2. Impulse response curve from Australia to Indonesia.

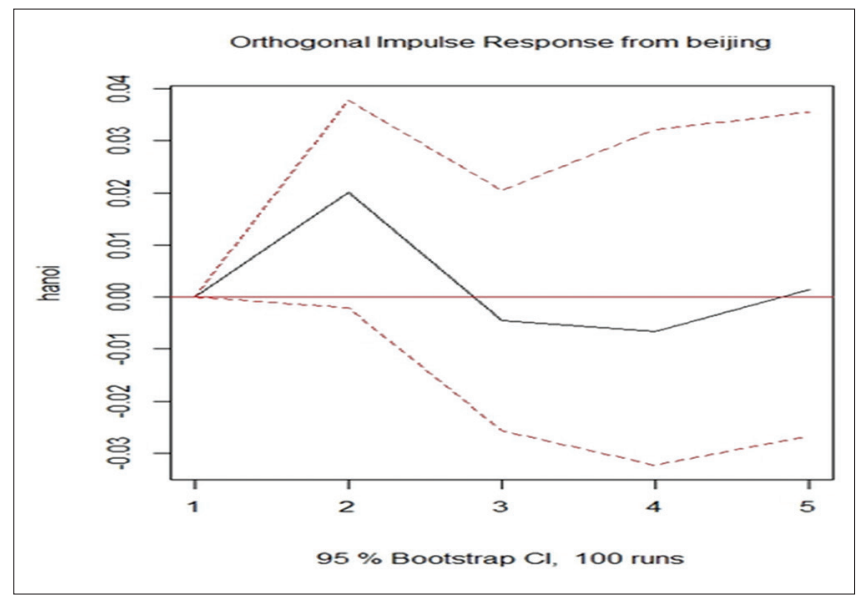

Fig 3. Impulse response curve from China to Vietnam.

Table 4: Granger causality test result

\begin{tabular}{lccc}
\hline Null hypothesis & Chi-square & df & P \\
\hline AU excluded VN & 0.3969 & 1 & 0.529 \\
CN excluded VN & 2.7604 & 1 & $0.047^{\star *}$ \\
ID excluded VN & 1.1197 & 1 & 0.290 \\
AU excluded ID & 17.529 & 1 & $0.000^{\star * *}$ \\
CN excluded ID & 0.1429 & 1 & 0.705 \\
VN excluded ID & 1.2312 & 1 & 0.267 \\
AU excluded CN & 0.0390 & 1 & 0.843 \\
VN excluded CN & 0.0130 & 1 & 0.909 \\
ID excluded CN & 1.3709 & 1 & 0.242 \\
CN excluded AU & 0.2566 & 1 & 0.612 \\
VN excluded AU & 2.1142 & 1 & 0.146 \\
ID excluded AU & 2.6640 & 1 & 0.103 \\
\hline
\end{tabular}

Note: AU excluded VN indicates the null hypothesis for this Granger Causality test is no causality, that is Australia beef price is not Granger causality for Vietnam beef price; $P$ value shows that test is rejected at $10 \%$ significance level.

\section{Factors influencing the price transmission}

Levels of price integration are low and insignificant in most (10 out of 12$)$ combinations of trading relationships. This is because the trade flows between these partners is relatively low as a proportion of all beef supplied in the country (both domestic supply and from other sources). However, in the trading relationships where there is high trade volumes, price integration is also high. While this may be expected, the relationships are not just influenced by formal trade flows but also by large informal trade flows and other factors not reflected in official data.

Unlike many other countries in Asia (Japan, South Korea, Malaysia, Singapore), the large majority of the beef consumed in the three countries under review (China, Vietnam, Indonesia) is sourced domestically (Table 6). However, imports in all three countries have grown to make up a significant proportion of beef supply. About $45 \%$ of the formal imports (145kt) of beef into China comes from Australia but this is a recent phenomenon with only $1 \mathrm{kt}$ in 2005 . Furthermore, even in the peak period of 2014, much larger volumes of beef (at least one million tonnes) were imported informally from other countries (India, Brasil, the US). With a small live cattle export flow (of mainly dairy and breeder cattle), the small proportion of beef (and cattle) exported from Australia to China is reflected in low price integration levels. Thus, studies have shown that international beef prices are the Granger cause of Chinese beef price (Zhao and Zhang, 2017), and prices in China are effected by countries other than Australia.

The Australia-Indonesia trade is highly complementary, based on geography, low transport costs and comparative advantage (Australia in cow-calf production and backgrounding and Indonesia in feeding and slaughter). Imports account for about 30\% of Indonesia's beef supply, dominated by both beef and live cattle exports from Australia, which together make up about $28 \%$ of domestic supply. Importantly, trade flows have been consistently high over the entire period of analysis (2005-15). This is reflected in the empirical analysis where the Indonesian beef market is integrated with the Australian beef market and where Australia is a price-maker and Indonesia is a price-taker.

It is difficult to quantify supply and trade volumes in Vietnam because it is simultaneously is a trade destination, source and transit country, with a "vibrant" flow cattle and beef through both formal and informal channels. Formal trade data drastically under-estimates the flows through the country. Exports (and re-exports) of beef from Vietnam to China was reported as zero in 2014. However there are estimates that two million tonnes of beef was informally imported into China in 2014 (Guo and Liang, 2015). More conservatively, the Chinese government reported that at least one million tonnes of bovine meat was informally imported into China in 2013 originating from India (470,000 tonnes), Brasil (430,000 tonnes) and the US 
Table 5: Results of vector error correction model

\begin{tabular}{|c|c|c|c|c|c|c|c|c|}
\hline & \multicolumn{2}{|c|}{$\triangle$ LNAU } & \multicolumn{2}{|c|}{$\triangle \mathrm{LNCN}$} & \multicolumn{2}{|c|}{$\triangle$ LNVN } & \multicolumn{2}{|c|}{$\triangle \mathrm{LNID}$} \\
\hline & Coef. & $z$ & Coef. & $z$ & Coef. & Z & Coef. & $z$ \\
\hline$\triangle \mathrm{LNAU}_{\mathrm{t}-1}$ & $0.3076^{\star \star}$ & 2.18 & 0.0322 & 0.27 & -0.1334 & -0.76 & $0.2497^{\star \star}$ & 2.08 \\
\hline$\triangle \mathrm{LNCN}_{\mathrm{t}-1}$ & -0.0163 & -0.11 & $0.4629^{* * *}$ & 3.65 & $0.3226^{*}$ & 1.73 & 0.0445 & 0.35 \\
\hline$\triangle \mathrm{LNVN}_{\mathrm{t}-1}$ & 0.1243 & 1.17 & -0.0034 & -0.04 & $-0.2192^{*}$ & -1.66 & 0.0668 & 0.74 \\
\hline$\triangle \mathrm{LNID}_{\mathrm{t}-1}$ & -0.1264 & -1.22 & 0.0622 & 0.71 & -0.1695 & -1.32 & $0.1608^{*}$ & 1.82 \\
\hline $\mathrm{ECM}_{\mathrm{t}-1}$ & -0.0153 & -0.84 & -0.0022 & -0.15 & -0.0323 & -1.44 & $-0.0698^{\star \star *}$ & -4.53 \\
\hline Cons & 0.0098 & 1.06 & $0.0135^{*}$ & 1.71 & 0.0015 & 0.13 & 0.0033 & 0.41 \\
\hline
\end{tabular}

Note: ${ }^{* \star *},{ }^{* \star}$ and ${ }^{*}$ denote significance at the $1 \%, 5 \%$ and $10 \%$ level, respectively.

Table 6: The proportion of Australian beef in total domestic beef supply in 2014 (kt)

\begin{tabular}{lcccc} 
& Australia & China & Vietnam & Indonesia \\
\hline Domestic supply & 983 & 7,437 & 348 & 714 \\
Domestic production & 2,595 & 6,107 & 345 & 498 \\
Net beef import/export & $-1,352$ & 1,279 & 709 & 54 \\
Volume from Australia & 0 & 145 & 55 \\
Next cattle import/export CWE & -260 & -- & $0 *$ & 38 \\
Volume from Australia & $98.4 \%$ & $2 \%$ & $25 \%$ & 146 \\
Proportion of Australia in total beef supply & & & $28 \%$ \\
\hline
\end{tabular}

Note: Domestic supply=Domestic production+Import - Export.

Sources: Domestic production statistics are drawn from country sources and revised according to methods described in Waldron et al. (2017). Formal trade data are drawn from UN Comtrade. This is supplemented with estimates of informal trade for China. This includes an additional one million tonnes of beef and 35,000 head of cattle smuggled into China and approximately 50,000 tonnes of beef and 20,000 head of cattle smuggled into Vietnam. Live exports of cattle from Australia to Indonesia and Vietnam are converted to cwe at carcass weights of 200kgs. While Australia exports live cattle to China these were predominantly dairy and breeding cattle in 2014 , a rate of $175 \mathrm{kgs}$ was used from Mekong countries.

(90,000 tonnes). ${ }^{1}$ Around 700,000 tonnes of this entered through Vietnam (Luong et al., 2015; Waldron et al., 2015). As a major conduit country, a significant volume and proportion of this smuggled beef is likely to have stayed in Vietnam. Furthermore, high prices in China increases pressure to sell Vietnamese product (both cattle and beef) into China. Thus, high/significant price integration between China and Vietnam, led by China, could not be explained through formal official statistics, but through unreported, informal statistics.

The proportion of Australian beef and cattle imports into Vietnam (25\%) are not dissimilar to Indonesia (28\%). However, this is only a recent phenomenon, with only small exports in previous years. It is also likely that Australia's more recent contribution to domestic supply is lower than this for two reasons. As outlined above, a part of the beef and cattle smuggled through Vietnam "leaks" into Vietnam, thus increasing domestic supply. Second, it is likely that a proportion of cattle and beef imported from Australia are "re-exported" through informal channels to China. The multitude of trade flows and channels in Vietnam, of which Australia is not a major source, may explain why the price of Australian beef has no a significant impact on the price of Vietnamese beef.

1 Joint report of the Anti-Smuggling Bureau of China Customs, MOFCOM China Chamber of Commerce of Foodstuffs and Native Produce Import and Export Association and COFCO.

\section{CONCLUSIONS}

Based on the time series data from 2005 to 2015, this paper analyzed the price transmission relationships of beef in four countries of Australia, China, Vietnam and Indonesia. Despite the rapid growth in Australian beef trade with China, Indonesia and Vietnam in the past 10 years, it was found that the impact of Australian beef price on Chinese and Vietnamese beef price was not significant and only had a significant impact on Indonesian beef price. The impacts are lagged one quarter and can last two consecutive quarters. Secondly, the price of Chinese beef has a significant impact on the price of beef in Vietnam, due to informal rather than formal trade flows. The impact again is lagged one quarter and lasts for two quarters. Thirdly, Australia and China markets are relatively independent from the other three countries with their price fluctuations only affected by their own prices.

The results are influenced primarily by the scale of trade and scales of exports (in the case of Australia) and imports (in the case of China). Large country effects on the price transmission of beef was proved to exist among four countries. Australia is a significant source of total beef supply in Indonesia, through formal beef and cattle exports. China is a large importer of beef, that comes from or - much more importantly - through Vietnam informally from third countries. A number of implications arise from the analysis, most notably that policy-makers, industry and other agencies in Indonesia and Vietnam that are concerned about food price 
inflation and security and trade policy - or who are assessing market opportunities - would benefit from observation of price trends and changes in Australia and China respectively.

\section{ACKNOWLEDGEMENT}

This research was supported by the Australian Centre for International Agricultural Research (ACIAR) and the China Scholarship Council (CSC). We sincerely thank Dr. Wang Mingli and Dr. Si Zhizhi from Chinese Academy of Agricultural Sciences for giving some good comments for this manuscript.

\section{Authors' contribution}

All authors contributed equally in this article.

\section{REFERENCES}

Chang, H. S. and G. Griffith. 1998. Examining long-run relationships between Australian beef prices. Aust. J. Agric. Resour. Econ. 42(4): 369-387.

Diakosavvas, D. 1995. How integrated are world beef markets? The case of Australian and U.S. beef markets. Agric. Econ. 12: 37-53.

Dong, X. X., S. W. Xu, Z. M. Li. and G. Q. Li. 2014. Price transmission mechanism of the poultry aquaculture in China-based on the FDL model. J. Agrot. Econ. 9: 52-60.

Dries, A. M. and L. Unnevehr. 1990. Influence of trade policies on price integration in the world beef market. Agric. Econ. 4(1): 73-89.

Engle, R. F. and C. W. J. Granger. 1987. Co-Integration and error correction: Representation, estimation and testing. Econometrica. 55(2): 251-276.

Fackler, P. L. and B. K. Goodwin. 2001. In: B. L. Gardner., G. C. Rausser (Ed.), Spatial Price Analysis, in Handbook of Agricultural Economics, Vol. 1B, Elsevier, Amsterdam, pp. 971-1024.

Fousekis, P., C. Katrakilidis. and E. Trachanas. 2016. Vertical price transmission in the US beef sector: Evidence from the nonlinear ARDL model. Econ. Model. 52(1): 499-506.

Ghoshray, A. 2011. Underlying Trends and International Price Transmission of Agricultural Commodities. Asian Development Bank Economics Working Paper Series No. 257. DOI: 10.2139/ ssrn. 1876185.

Gonzalez, R. G. and S. M. Helfand. 2001. The extent, pattern, and degree of market integration: A multivariate approach for the Brazillian rice market. Am. J. Agric. Econ. 83(3): 576-592.

Goodwin, B. K. and M. T. Holt. 1999. Price transmission and asymmetric adjustment in the U.S. Beef Sector. Am. J. Agric. Econ. 81(3): 630-637.

Granger, C. W. J. 2004. Time series analysis, co-integration, and applications. Am. Econ. Rev. 94(3): 421-425.

Griffith, G. R. and N. E. Piggott. 1994. Asymmetry in beef, lamb and pork farm-retail price transmission in Australia. Agric. Econ. 10(3): 307-316.
Guo, S. L. and Y. J. Liang. 2015. 2 million tons of smuggled meat sales throughout the country every year. Agric. Rural. Farm. 5: 20-22.

Harris, R. I. D. 1995. Using Co-Integration Analysis in Econometric Modelling, Vol. 82, Prentice Hall, London.

Bakucs, L. Z. and I. Fertő. 2006. Marketing margins and price transmission on the Hungarian beef market. Acta Agric. Scand Sec. C. 3(3-4): 151-160.

Lele, U. J. 1967. Market integration: A study of sorghum prices in western Indian. J. Farm Econ. 49 (1 part I): 147-159.

Listorti, G. and R. Esposti. 2012. Horizontal price transmission in agricultural markets: Fundamental concepts and open empirical issues. Biobased Appl. Econ. 1(1): 81-108.

Lloyd, T. A., S. McCorriston, C. W. Morgan and A. J. Rayner. 2006. Food scares, market power and price transmission: The UK BSE crisis. Eur. Rev. Agric. Econ. 33(2): 119-147.

Miljkovic, D. 1999. The law of one price in international trade: A critical review. Rev. Agric. Econ. 21(1): 126-139.

Narayan, P. K. and R. Smyth. 2004. Temporal causality and the dynamics of exports, human capital and real income in China. Int. J. Appl. Econ. 1(1): 24-45.

Pozo, V. F., T. C. Schroeder. and L. J. Bachmeier. 2013. Asymmetric Price Transmission in the U.S. Beef Market: New Evidence From New Data. Proceedings of the NCCC-134 Conference on Applied Commodity Price Analysis, Forecasting, and Market Risk Management, St. Louis, MO. Available from: http://www. farmdoc.illinois.edu/nccc134.

Sanjuán, A. I. and P. J. Dawson. 2003. Price transmission, BSE and structural breaks in the UK meat sector. Eur. Rev. Agric. Econ. 30(2): 155-172.

Thakur, D. S. 1974. Food grain marketing efficiency: A case study of Gujurat. Indian J. Agric. Econ. 29(4): 61.

Theodoros, K., Z. Eleni. and A. Garyfallos. 2009. Asymmetry in price transmission between the producer and the consumer prices in the wood sector and the role of imports: The case of Greece. Forest Policy Econ. 11(1): 56-64.

Timmer, M. P. 1999. Indonesia's ascent on the technology ladder: Capital stock and total factor productivity in Indonesian manufacturing, 1975-1995. Bull. Indones. Econ. Stud. 35(1): 75-97.

Waldron, S., D. Smith, L. Pham and S. P. Hieu. 2017. Macro Developments in the China and Southeast Asia Beef Sector. Contributed Paper, 2017 Conference of the Australasian Agricultural and Resources Economics Society, Brisbane.

Waldron, S., J. M. Wang, H. J. Zhang, X. X. Dong. and M. L. Wang. 2015. The Chinese Beef Industry in "Regional workshop on beef markets and trade in Southeast Asian and China", Ben Tre, Vietnam.

Yoon, J. and S. Brown. 2016. Beef Market Integration and Price Transmission in the Trans-Pacific Partnership (TPP) Countries, Climate Change and International Agricultural Trade in the Aftermath of COP21, Scottsdale, Arizona.

Zhao, H. X. and Y. J. Zhang. 2017. Research on VAR-based beef prices at home and abroad of the space market integration. Jilin Nong Ye Da Xue Xue Bao. 1: 33-40. 